УДК 349.2

DOI https://doi.org/10.32844/2618-1258.2019.5-1.28

ДРОЗД С.М.

\title{
СИСТЕМА СУБ'СКТІВ ФІНАНСУВАННЯ МЕДИЧНОГО ЗАБЕЗПЕЧЕННЯ ПОЛІЦЕЙСЬКИХ
}

У статті визначається значення та роль фінансування медичного забезпечення поліцейських. Також з'ясовується сутність таких основних понять, як «медична допомога» $\mathrm{i}$ «медична послуга». Так, «медична допомога» $\mathrm{i}$ «медичні послуги» різними фахівцями трактуються по-різному: і як синоніми, і як антоніми, і як складники одне одного, і як такі, що узагальнюють обидві категорії.

Поняття «медична допомога» переважно охоплює лікування, профілактичні заходи, які провадяться під час захворювань, травм, пологів, а також медичний огляд та деякі інші види медичних робіт. Зміст же близького до «медичної допомоги» поняття «медична послуга» до теперішнього часу залишається невизначеним не лише в нормативних актах, але й у медичній літературі.

Також у статті вказується на відсутність медичних стандартів надання первинної та вторинної медичної допомоги, або ж їх застарілість, що своєю чергою є фактично єдиним правовим критерієм встановлення правоти чи неправоти лікаря та лікувального закладу під час лікувального процесу.

Медичне забезпечення поліцейських має чітко виражену соціальну функцію, що є складником соціальної політики держави. Своєю чергою реалізацію державної політики у сфері медичного забезпечення поліцейських покладено на Міністерство внутрішніх справ України та Національну поліцію України.

Виділено причини, які зумовлюють відмінності функціональної діяльності поліцейського від інших професій. Зазначено державні органи, які в межах наданих їм повноважень забезпечують фінансування медичного забезпечення поліцейських. Окрім цього, викладено правові принципи організації медичного забезпечення поліцейських.

У прикінцевій частині статті визначено уповноважений підрозділ, який входить до системи Міністерства внутрішніх справ України та здійснює реалізацію державної політики у сфері організації медичного забезпечення поліцейських. Також зазначено підрозділи, що входять до складу Управління охорони здоров'я та реабілітації МВС України.

Враховуючи досвід фінансування медичного забезпечення поліцейських у розвинених країнах світу, у статті запропоновано комплекс заходів, спрямованих на підвищення якості фінансового забезпечення закладів охорони здоров'я системи МВС України.

Ключові слова: охорона здоров'я, медична допомога, медичні послуги, державне регулювання, Національна полічія України, територіальні медичні об'єднання, медичні реабілітаційні иентри.

The article defines the importance and role of financing the health care of police officers. It also clarifies the essence of such basic concepts as "medical care" and "medical service". Thus, "medical care" and "medical services" are interpreted differently by different specialists: both as synonyms and as antonyms, as components of each other, and as generalizations of two categories.

The concept of "medical assistance" mainly covers treatment, preventive measures taken in the event of illness, injury, childbirth, as well as medical examination and some other types of medical work. The meaning of the concept of "medical service", which is close to "medical aid", is still vague not only in the normative acts, but also in the medical literature.

( С ДРОЗД С.М. - здобувач наукового ступеня доктора філософії (кандидата наук) кафедри фінансового права та фіскального адміністрування (Національна академія внутрішніх справ) 
The article also points to the lack of medical standards for the provision of primary and secondary care, or their obsolescence, which is, in turn, the only legal criterion for establishing the right or wrong of a doctor and medical establishment during the treatment process.

The medical provision of police officers has a distinct social function, which is an integral part of the state's social policy. In turn, the implementation of the state policy in the field of health care for police is entrusted to the Ministry of Internal Affairs of Ukraine and the National Police of Ukraine.

The reasons that distinguish the functional activity of the police officer from other professions are highlighted. The state bodies, which within the limits of their powers provide financing of medical support to police, are indicated. In addition, the legal principles of organizing medical care for police officers are outlined.

The final part of the article identifies the authorized unit that is part of the system of the Ministry of Internal Affairs of Ukraine and implements the state policy in the field of organization of medical care for police. The units within the Health and Rehabilitation Department of the Ministry of Internal Affairs of Ukraine are also indicated.

Taking into account the experience of financing the health care of police officers in the developed countries of the world, the article proposes a set of measures aimed at improving the quality of financial support of health care institutions of the Ministry of Internal Affairs of Ukraine.

Key words: health care, aid, medical services, state regulation, National Police of Ukraine, territorial medical associations, medical rehabilitation centers.

Вступ. Право на медичну допомогу і охорону здоров'я $є$ базовим у системі соціальних прав людини. Здоров'я населення загалом і кожного громадянина зокрема має важливе значення для існування і розвитку держави. Сфера охорони здоров'я являє собою складний комплекс суспільних відносин - фінансових, правових, управлінських, медичних, організаційних тощо, що регулюються різними галузями права - адміністративним, фінансовим, податковим, бюджетним, господарським та іншими. Разом з тим центральною ланкою у системі охорони здоров'я виступають відносини, які виникають між суб'єктами, що надають медичні послуги та медичну допомогу, а також державою (в особі уповноважених органів), що здійснює фінансування медичного забезпечення [1, с. 5].

Постановка завдання. Мету статті можна сформулювати як з'ясування системи суб'єктів фінансування медичного забезпечення поліцейських, а також визначення комплексу заходів, спрямованих на підвищення якості фінансового забезпечення закладів охорони здоров'я системи МВС України.

Результати дослідження. Юридична наука та практика не мають значного досвіду взаємодії зі сферою охорони здоров'я. Відомо, що до 90-х років ХХ століття правове регулювання фінансування медичного забезпечення здійснювалося загалом поверхнево і особливої уваги з боку наукових кіл не відмічалося.

Розвиток в Україні ринку медичних послуг та медичної допомоги ставить питання про місце і роль системи суб'єктів фінансування медичного забезпечення поліцейських під іншим наголосом. Це змушує шукати нові системні підходи до проблеми належного фінансування медичного забезпечення поліцейських.

За період незалежності нашої держави було прийнято значну кількість законодавчих та нормативно-правових актів у сфері фінансування медичного забезпечення поліцейських. Але і до цього часу відчувається недостатність фінансово-правового регулювання цієї сфери суспільних відносин. Проте за останні два десятиліття розбудови країни стало очевидним, що система медичного забезпечення поліцейських, доступність та якість медичних послуг, а також захист прав пацієнтів, як складники прав людини, поки ще не стали пріоритетними напрямами політики держави.

Зауважимо, що досить тривалий час у вітчизняному законодавстві були відсутні визначення таких основних понять, як «медична допомога» $\mathrm{i}$ «медична послуга». Так, «медична допомога» i «медичні послуги» різними фахівцями трактуються по-різному: і як синоніми, і як антоніми, і як складники одне одного, і як такі, що узагальнюють обидві категорії [2, с. 145]. У рішенні Конституційного Суду України від 25.11.98 р. № 15-рп/98 (справа про платні медичні послуги) відмічається у зв'язку з цим таке: «Зміст поняття «медична допомога» Конституція Украї- 
ни не розкриває. Відсутнє його значення також в Основах законодавства про охорону здоров'я та інших нормативно-правових актах. Однак у медичній науці поняттям «медична допомога» переважно охоплюється лікування, профілактичні заходи, які провадяться під час захворювань, травм, пологів, а також медичний огляд та деякі інші види медичних робіт. Зміст же близького до «медичної допомоги» поняття «медична послуга» до теперішнього часу залишається невизначеним не тільки в нормативних актах, але й у медичній літературі» [3, с. 119].

Іншим не менш актуальним питанням системи медичного забезпечення поліцейських $\epsilon$ відсутність медичних стандартів надання первинної та вторинної медичної допомоги, або ж їх застарілість, що своєю чергою є фактично єдиним правовим критерієм встановлення правоти чи неправоти лікаря та лікувального закладу під час лікувального процесу. 3 юридичного погляду надзвичайно важливою $є$ також відсутність зрозумілих критеріїв, еталонів, з якими можна порівняти бажану та/або рекомендовану поведінку лікаря в тому чи іншому разі та фактично призначені ним медичні процедури чи медичні засоби [4, с. 108].

Проте навіть наявності сучасних стандартів надання медичної допомоги не достатньо для належного регулювання відносин між лікувальним закладом та пацієнтом (у нашому прикладі поліцейським), оскільки основним критерієм надання якісного медичного забезпечення є його належне фінансування.

Медичне забезпечення поліцейських має чітко виражену соціальну функцію, що є складником соціальної політики держави. Своєю чергою реалізацію державної політики у сфері медичного забезпечення поліцейських покладено на Міністерство внутрішніх справ України та Національну поліцію України.

Зазначимо, що причин, які зумовлюють відмінності функціональної діяльності поліцейського від інших професій, достатньо, основні з них можна виокремити в три групи:

- соціальні (підвищений професійний ризик під час виконання своїх професійних обов'язків, порушення умов праці);

- особисті (значні психоемоційні навантаження, вплив факторів, що деформують правосвідомість);

- комплексні (високий рівень травматизму, професійні захворювання).

Поділяючи та підтримуючи засади державного регулювання медичного забезпечення поліцейських, слід забезпечувати здійснення злагоджених дій щодо фінансування цієї сфери відносин на рівні всієї держави із залученням:

- Верховної Ради України (прийняття законів, положення яких визначають мінімальні рівні соціальної захищеності поліцейських);

- Міністерства внутрішніх справ України (безпосереднє втілення соціальних нормативів на практиці);

- Національної поліції України (формування списків поліцейських та переліку посад, що передбачають відомче медичне забезпечення);

- Міністерства соціальної політики України (розроблення нормативів праці, правил соціальної адаптації осіб, звільнених з органів поліції, тощо);

- Міністерства освіти і науки України (розробка навчальних програм, спрямованих на підвищення кваліфікації, перепідготовку поліцейських);

- Міністерства фінансів України (фінансування заходів, спрямованих на забезпечення соціальної захищеності поліцейських);

- Міністерства охорони здоров'я України (взаємодія із системою відомчої медицини в питаннях медичного складника соціальної захищеності); ських).

- громадських організацій (відстоювання прав, свобод та законних інтересів поліцей-

Варто вказати, що правові принципи організації медичного забезпечення поліцейських доцільно розділити на дві групи:

а) загальнодержавні - це ключові засади організації медичного забезпечення, котрі містяться в законодавчих актах і визначають основні напрями організації охорони здоров'я як у цивільній, так і у відомчій медицині системи Міністерства внутрішніх справ України.

До них, керуючись комплексним сприйняттям медичної діяльності, можуть бути віднесені: принцип віднесення медичного забезпечення поліцейських до факторів забезпечення національної безпеки; пріоритетність фінансування медичного забезпечення поліцейських; загальнодоступність медичного забезпечення поліцейських; безоплатність медичного забезпечення поліцейських. 


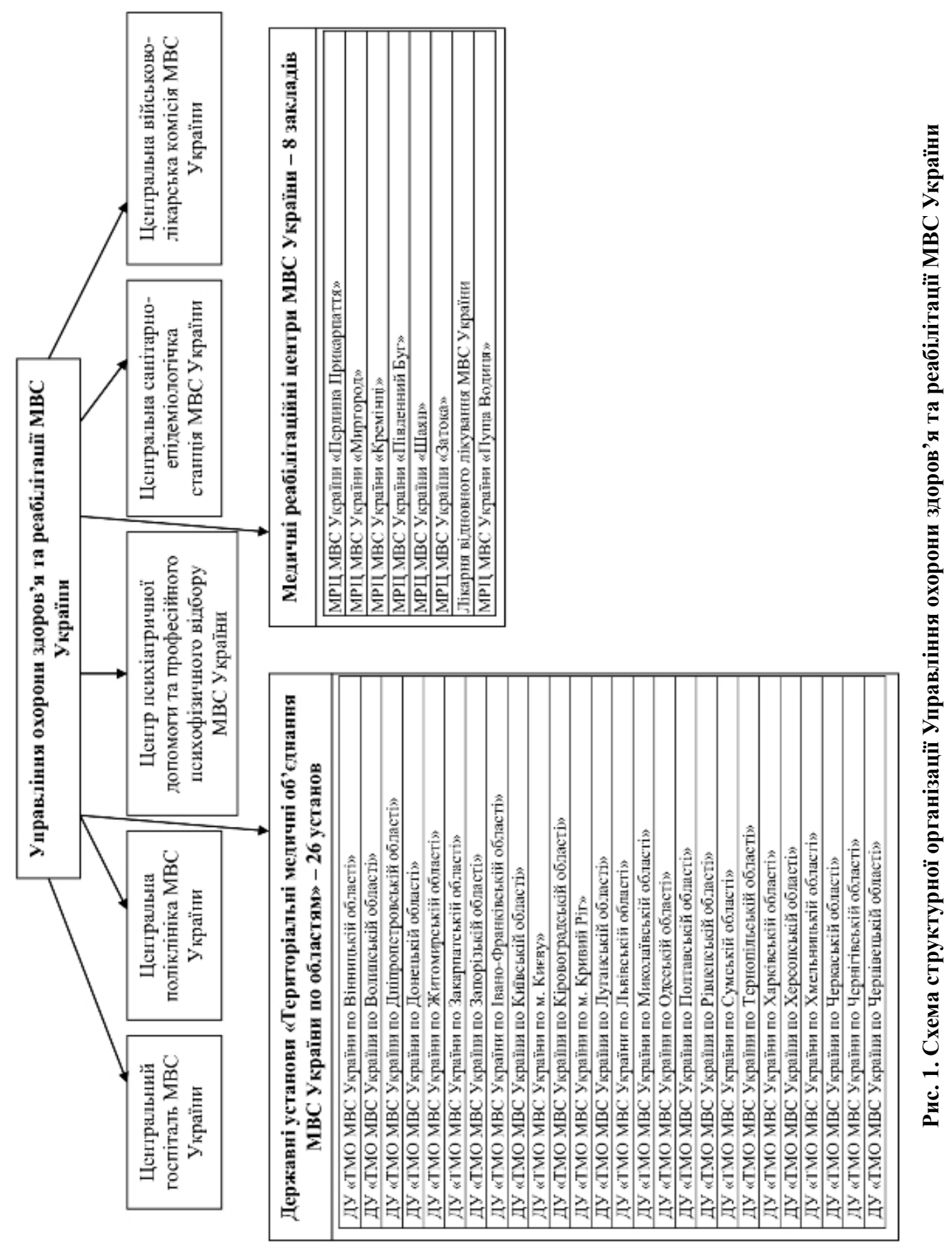


б) внутрішньосистемні правові принципи організації медичного забезпечення поліцейських - це ключові засади організації медичного забезпечення поліцейських, котрі переважно містяться в підзаконних нормативно-правових актах і визначають основні напрями організації медичного забезпечення у відомчій медицині системи Міністерства внутрішніх справ України.

До внутрішньосистемних принципів організації медичного забезпечення поліцейських у системі Міністерства внутрішніх справ України можуть бути віднесені такі: профілактична спрямованість; пріоритет первинної медичної допомоги; включення фармацевтичного забезпечення у перелік безоплатної медичної допомоги; наукова обгрунтованість організаційно-штатної структури Управління охорони здоров’я та реабілітації МВС України [5, с. 8-9].

Також слід зазначити, що в системі Міністерства внутрішніх справ України уповноваженим підрозділом, який здійснює реалізацію державної політики у сфері організації медичного забезпечення поліцейських, $є$ Управління охорони здоров'я та реабілітації МВС України.

Склад Управління охорони здоров'я та реабілітації МВС України наведено на рисунку 1.

Висновки. Враховуючи досвід фінансування медичного забезпечення поліцейських у розвинених країнах світу, варто запропонувати комплекс заходів, спрямованих на підвищення якості фінансового забезпечення закладів охорони здоров'я системи МВС України:

- визначення гарантованого державою обсягу безоплатних медичних послуг для поліцейських і забезпечення необхідного розміру фінансових ресурсів для організації їх надання;

- введення права співучасті поліцейських в оплаті медичних послуг (послуги підвищеної комфортності, витрати на госпіталізацію понад установлений нормативами термін лікування тощо);

- розширення переліку платних послуг, які можуть надавати безпосередньо територіальні медичні об'єднання та медичні реабілітаційні центри, розроблення методики визначення їх вартості;

- відмову від принципу фінансування витрат (утримання) територіальних медичних об'єднань та медичних реабілітаційних центрів і перехід до контрольних закупівель медичних послуг за моделлю блок-контракту;

- формування багатоканальної моделі фінансування медичного забезпечення поліцейських із залученням бюджетних коштів як основного джерела фінансових ресурсів, коштів від медичного страхування, надання платних медичних і немедичних послуг, благодійних внесків, кредиту, лізингу та інших джерел, не заборонених законодавством;

- перенесення пріоритету на фінансування територіальних медичних об'єднань та медичних реабілітаційних центрів, які забезпечують надання первинної медико-санітарної та амбулаторно-поліклінічної допомоги;

- запровадження стаціонарозамінних та ресурсоощадних технологій, оптимізація потужності територіальних медичних об'єднань та медичних реабілітаційних центрів, підвищення ефективності капіталовкладень [6, с. 472].

\section{Список використаних джерел:}

1. Болотіна Н.Б. Медичне право Украйни: Збірник нормативно-правових актів. Київ : Видавничій Дім «Ін Юре», 2001. 412 с.

2. Медицинское право Украины: Учебное пособие / В. Волков, Л. Дешко, В. Заблоцкий и др. Донецк : ДонНу, 2005. 268 с.

3. Рішення Конституційного Суду України від 25.11.1998 № 15-рп/98 у справі за конституційним поданням 66 народних депутатів України щодо відповідності Конституції України (конституційності) Постанови Кабінету Міністрів України «Про затвердження переліку платних послуг, які надаються в державних закладах охорони здоров'я та вищих медичних закладах освіти» (справа про платні медичні послуги). Офіиійний вісник Украйни від 31.12.1998. 1998 р., № 50 , c. 119 .

4. Губський Ю., Сердюк В., Царенко А. та ін. Правове регулювання надання медичної допомоги в Україні. Медичне право Украӥни: проблеми становлення та розвитку. Матеріали I Всеукраїнської науково-практичної конференції. Львів, 2007. 247 с.

5. Тихомирова Т. Реалізація державної політики охорони здоров'я в системі МВС України: адміністративно-правовий аспект. 12.00.07 - адміністративне право і процес; фінансове право; інформаційне право. Київ, 2010. 20 с.

6. Бюджетна система: підручник. Київ : ЦУЛ, 2017. 871 с. 